\title{
Morfometrik Ayam Broiler dengan Pemeliharaan Intensif dan Akses Free Range di Daerah Tropis
}

\author{
Morphometric Analysis of Broiler Chicken under Intensive Rearing and Free Range Access System in \\ Tropical Region
}

\author{
I. Rahayu H. S., S. Darwati, \& A. Mu'iz \\ Departemen Ilmu Produksi dan Teknologi Peternakan, Fakultas Peternakan, IPB \\ Jl. Agatis Kampus IPB Dramaga, Bogor, 16680 \\ Email koresponden author: rahayu21@hotmail.com
}

\begin{abstract}
Broiler developed to produce meat in a fast manner. Generally, broiler reared by intensive system. Rearing system can be split into two kinds, intensive and free-range rearing system. The aim of this research was assessing the morphometric size of male and female broiler which are raised under intensive and free-range systems. Rearing systems was not have influence on the morphometric size of the chicken except in the length of the tibia, femur, and wing on the third week. Sex have real impact on the length of shank, tibia, wings, femur, and chest circumference, and also significantly affect the width and depth of the chest, neck, and spine lenght in fifth week. Rearing systems both intensive and free-range produced same frame size on broiler chicken.
\end{abstract}

Keywords: broiler, morphometric, free range

\section{PENDAHULUAN}

Daging unggas terutama daging ayam merupakan sumber protein hewani yang sangat diminati di Indonesia. Masyarakat Indonesia sudah tidak asing lagi dengan daging ayam broiler karena memiliki harga yang relatif terjangkau dan dapat dicari dengan mudah di pasaran. Data BPS (2016) menyebutkan pada tahun 2013 produksi ayam broiler mencapai 1344191104 ekor, peningkatan ayam broiler terus terjadi dengan rata-rata penambahan populasi 90793 344.8 ekor setiap tahunnya. Populasi ayam broiler tahun 2017 diketahui mencapai 1698368741 ekor.

Ayam broiler merupakan ayam yang dikembangkan untuk memproduksi daging secara cepat. Broiler merupakan ternak unggas yang memiliki laju pertumbuhan yang sangat cepat dengan target panen kurang dari 5 minggu dengan bobot badan sekitar $1.7 \mathrm{~kg}$ / ekor. Keunggulan broiler didapat dari proses seleksi yang sangat ketat sehingga didapatkan sifat genetik yang unggul dengan kondisi pemeliharaan yang terkontrol meliputi makanan, temperatur lingkungan, dan manajemen pemeliharaannya (Umam 2015). Penampilan broiler sebagai ayam pedaging yang bagus dapat dicapai dengan sistem pemeliharaan intensif modern dengan ciri-ciri pemakaian bibit unggul, pakan berkualitas, dan lingkungan kandang yang terkontrol penuh.

Tingkat keberhasilan dalam pemeliharaan dapat dipengaruhi oleh kandang, karena broiler merupakan ternak yang memiliki ketahanan tubuh yang rendah sehingga sangat sensitif terhadap suhu, kelembaban, dan sirkulasi udara (Umam 2015).

Kandang dengan akses ke free-range adalah sistem yang dibuat untuk ternak dengan harapan ayam dapat hidup dan mengekspresikan instingnya secara alami (Castellini 2002). Free-range merupakan salah satu cara memelihara ternak dengan memperhatikan asas animal welfare yang dirumuskan oleh The Royal Society for Prevention of Cruelty to Animal (RSPCA). Ternak yang diperlakukan dengan cara welfare akan dapat lebih leluasa bergerak dan mengekspresikan tingkahlaku alaminya sehingga dapat mengurangi tingkat stres (Kiswanto 2014). Kenyamanan yang diberikan terhadap ternak diharapkan dapat mengoptimalkan pertumbuhan ternak. Sistem budidaya ber akses free-range baik untuk usaha peternakan ayam ras pada skala usaha kecil di pedesaan, karena tidak memerlukan banyak modal untuk membuat kandang. Disamping itu produk peternakan yang dihasilkan secara alami diyakini sebagai makanan yang lebih sehat dibanding dengan produk unggas yang dihasilkan dari sistem budidaya intensif. Produk free-range memiliki nilai ekonomis yang lebih tinggi di pasaran dan di Indonesia masih sedikit peternak yang memperhatikan faktor animal welfare. Kurangnya sumber data dan penelitian dalam sistem budidaya free-range pada ternak ayam broiler menjadikan sistem budidaya free-range kurang diminati.

Penelitian ini difokuskan pada pengamatan ukuran tubuh (morfometrik) yang umumnnya digunakan untuk 
memprediksi bobot badan dan komposisi karkas ayam. Morfometrik merupakan indikator yang baik dan memiliki nilai korelasi yang cukup erat dengan parameter bobot hidup (Suparyanto 2004). Pengukuran juga dapat menjadi indikator dalam proses seleksi ayam (Kurnianto 2013). Ayam broiler sudah melalui proses seleksi genetik yang ketat tetapi proses penyeleksian dan pemeliharaan biasanya dilakukan pada kandang yang terkontrol (intensif). Penelitian terkait aktivitas ayam broiler dengan cara umbaran (akses free-range) belum banyak dilakukan. Melalui penelitian ini dapat dikaji pemeliharaan dengan cara umbaran (akses freerange) dapat dilakukan tanpa mengurangi potensi genetik ayam broiler.

\section{MATERI DAN METODE}

\section{Waktu dan Tempat Penelitian}

Penelitian ini dilaksanakan di Laboratorium Lapang Blok B bagian Unggas, Fakultas Peternakan, Institut Pertanian Bogor. Penelitian dilakukan pada bulan Maret 2018 sampai Agustus 2018. Maret sampai Juli 2018 dilakukan persiapan area free-range dan penanaman rumput dan Juli sampai Agustus 2018 dilakukan pemeliharaan ayam dan pengambilan data.

\section{Materi}

Sebelum ternak datang dilakukan persiapan kandang meliputi penanaman rumput gajah mini yang ditanam pada area free-range sampai rumput tumbuh dengan merata, kemudian pembersihan ruangan kandang dari kotoran dan debu, membersihkan lantai serta area kandang dengan menggunakan desinfektan dan kapur. Setelah pembersihan kandang dilakukan kemudian memasang bola lampu 60 watt pada setiap kandang untuk pemanas buatan (brooder), memberikan alas (koran) pada masing-masing lantai kandang, menyiapkan tempat pakan dan air minum.

Pada saat anak ayam datang, terlebih dahulu dilakukan penimbangan bobot badan untuk memperoleh kisaran berat badan awal. Setelah itu ayam-ayam dibagimenjadi 8 kelompok. Penempatan ayam ke masingmasing kandang dilakukan secara acak. Penomoran anak ayam dengan memberikan wing band pada sayap kanan DOC.

Pada minggu pertama, pakan diberikan ad libitum yang diberikan 4 kali sehari. Pakan yang diberikan pada anak ayam adalah pakan komersial. Untuk membantu menanggulangi adanya cekaman akibat penanganan pada minggu pertama, pada keadaan cuaca tidak baik maka ayam diberi vitamin (vitachick) yang dilarutkan dalam air dengan dosis $5 \mathrm{~g}$ tiap $12 \mathrm{~L}$ air minum. Pemberian vitamin (vitastress) juga dilakukan setelah proses pengambilan data untuk meminimalisir terjadinya stress pada ayam. Vaksinasi ulang tidak dilakukan dalam penelitian karena DOC (Day Old Chick) yang digunakan sudah divaksinasi.

Setelah umur ayam 3 minggu, akses kandang freerange yang terhubung ke area terbuka (rumput) dibuka, sedangkan ayam yang ada di dalam kandang intensif dipelihara sampai umur 5 minggu. Ayam broiler dibiarkan beraktivitas di area free-range yang ditumbuhi rumput gajah mini dari pukul 07.00-17.00 setiap hari. Pakan diberikan dengan ketentuan yang sama dan waktu yang sama antar perlakuan. Pakan dan minum ayam free-range ditempatkan di area dalam dan umbaran. Free-range merupakan area yang digunakan untuk memelihara ayam dengan lebih memerhatikan kesejahteraan hewan. Area free-range yang digunakan seluas 4,0 × 4,5 m yang ditumbuhi rumput gajah mini. Ayam diberi akses untuk memiliki ruang gerak yang lebih luas tetapi masih dalam pengawasan. Pagar kawat besi digunakan untuk mencegah ayam keluar dari area yang ditentukan dan mencegah bahaya dari hewan predator seperti kucing dan yang lainnya. Atap juga diberi peneduh transparan agar ayam dapat terus diumbar pada saat hujan turun. Rumput disiram pada pukul 17.00 setelah ayam dimasukan agar rumput tetap tumbuh.

\section{Analisis Data}

Analisis secara deskriptif digunakan untuk mengetahui rataan $(\overline{\mathrm{x}})$ dansimpangan baku (sd). Uji t digunakan untuk mengetahui perbedaan rataan data hasil pengukuran ayam jantan intensif dengan ayam jantan freerange dan ayam betina intensif dengan ayam betina freerange. Rumus uji t menurut Mattjik dan Sumertajaya (2013):

$$
\mathrm{t}=\frac{\left(\overline{\mathrm{x}}_{1}-\overline{\mathrm{x}}_{2}\right)}{\left[\frac{\mathrm{S}_{1^{2}}}{n_{1}}+\frac{\mathrm{S}_{2^{2}}}{n_{2}}\right]^{1 / 2}}
$$

Keterangan:

$\mathrm{X}_{1}=$ Rataan data 1

$\mathrm{X}_{2}=$ Rataan data 2

$\mathrm{S}_{1}=$ Simpangan baku 1

$\mathrm{S}_{2}=$ Simpangan baku 2

$\mathrm{n}_{1}=$ Jumlah sampel 1

$\mathrm{n}_{2}=$ Jumlah sampel 2

\section{HASIL DAN PEMBAHASAN}

\section{Pengaruh Sistem Pemeliharaan pada Ayam Jantan}

Ayam broiler jantan yang dapat diambil data dalam penelitian berjumlah 84 ekor, 38 ekor dipelihara secara intensif dan 46 ekor dipelihara secara free-range. Data hasil pengukuran morfometrik ayam broiler jantan disajikan pada Tabel 1. Hasil analisis data menunjukan bahwa perbedaan sistem pemeliharaan pada ayam broiler jantan hanya berpengaruh nyata $(\mathrm{P}<0,05)$ pada panjang sayap saat ayam berumur 3 minggu. Panjang sayap ayam free-range lebih panjang dari ayam intensif. Hal ini disebabkan ayam yang dipelihara dengan sistem free-range memiliki ruang gerak lebih luas dibandingkan ayam yang dipelihara secara intensif. Menurut Fortomaris (2006) bagian ayam yang lebih banyak digerakan memiliki pertumbuhan tulang yang lebih maksimal.

\section{Pengaruh Sistem Pemeliharaan pada Ayam Betina}

Hasil dari analisis sederhana koefisien korelasi dari linier ukuran tubuh terhadap bobot badan ayam broiler disajikan pada Tabel 2. Ayam broiler betina yang dapat diambil data dalam penelitian berjumlah 108 ekor, 60 ekor dipelihara secara intensif dan 48 ekor dipelihara secara free-range. Data hasil pengukuran morfometrik ayam 
Tabel 1. Rataan hasil pengukuran morfometrik ayam jantan

\begin{tabular}{|c|c|c|c|}
\hline \multirow[t]{2}{*}{ Peubah } & \multirow[t]{2}{*}{$\begin{array}{c}\text { Minggu } \\
\text { ke - }\end{array}$} & \multicolumn{2}{|c|}{$\begin{array}{l}\text { Rataan } \pm \text { sd Ukuran Tubuh pada } \\
\text { Sistem Pemeliharaan (mm) }\end{array}$} \\
\hline & & $\begin{array}{l}\text { Intensif } \\
(\mathrm{n}=38)\end{array}$ & $\begin{array}{l}\text { Free-range } \\
\quad(\mathrm{n}=46)\end{array}$ \\
\hline \multirow[t]{2}{*}{ Panjang paruh } & 3 & $24,05 \pm 2,23$ & $23,85 \pm 1,56$ \\
\hline & 5 & $28,00 \pm 2,87$ & $27,67 \pm 1,73$ \\
\hline \multirow[t]{2}{*}{ Panjang shank } & 3 & $49,63 \pm 5,02$ & $50,89 \pm 5,77$ \\
\hline & 5 & $65,11 \pm 11,48$ & $65,65 \pm 8,15$ \\
\hline \multirow[t]{2}{*}{ Panjang tibia } & 3 & $77,35 \pm 13,04$ & $78,68 \pm 9,40$ \\
\hline & 5 & $92,09 \pm 12,15$ & $92,69 \pm 10,80$ \\
\hline \multirow[t]{2}{*}{ Panjang femur } & 3 & $60,77 \pm 4,49$ & $60,28 \pm 6,78$ \\
\hline & 5 & $76,54 \pm 8,88$ & $77,28 \pm 7,65$ \\
\hline \multirow[t]{2}{*}{ Panjang sayap } & 3 & $154,92 \pm 19,35 \mathrm{a}$ & $163,26 \pm 14,30 b$ \\
\hline & 5 & $212,46 \pm 19,44$ & $207,66 \pm 14,51$ \\
\hline \multirow[t]{2}{*}{ Dalam dada } & 3 & $72,52 \pm 10,15$ & $71,50 \pm 6,76$ \\
\hline & 5 & $90,50 \pm 13,62$ & $87,04 \pm 9,95$ \\
\hline \multirow[t]{2}{*}{ Lebar dada } & 3 & $61,27 \pm 4,59$ & $61,29 \pm 6,56$ \\
\hline & 5 & $91,40 \pm 8,37$ & $90,75 \pm 9,31$ \\
\hline \multirow[t]{2}{*}{ Panjang dada } & 3 & $93,21 \pm 15,21$ & $95,75 \pm 8,66$ \\
\hline & 5 & $147,95 \pm 13,78$ & $142,91 \pm 17,28$ \\
\hline \multirow[t]{2}{*}{ Panjang leher } & 3 & $88,89 \pm 19,25$ & $96,35 \pm 20,62$ \\
\hline & 5 & $112,92 \pm 16,26$ & $118,93 \pm 19,25$ \\
\hline \multirow[t]{2}{*}{ Panj. punggung } & 3 & $139,82 \pm 9,64$ & $134,70 \pm 15,19$ \\
\hline & 5 & $155,66 \pm 12,65$ & $156,61 \pm 14,72$ \\
\hline \multirow[t]{2}{*}{ Lingkar dada } & 3 & $233,47 \pm 12,59$ & $235,65 \pm 20,23$ \\
\hline & 5 & $331,74 \pm 22,13$ & $328,76 \pm 25,45$ \\
\hline
\end{tabular}

broiler betina disajikan pada Tabel 2. Sistem pemeliharaan berpengaruh nyata $(\mathrm{P}<0,05)$ pada panjang femur dan panjang tibia minggu ke-3 untuk ayam broiler betina. Panjang femur dan tibia pada ayam betina intensif lebih panjang dibandingkan ayam betina free-range. Tibia merupakan salah satu tulang yang memiliki pertumbuhan lambat (Candrawati 2007). Panjang tibia betina yang dipelihara di free-range lebih pendek dibanding ayam betina intensif. Hal ini dimungkinkan karena ayam betina memiliki bobot badan yang kecil (Candrawati 2007). Ayam yang dipelihara di free-range mengkonsumsi daun dari rumput gajah mini yang tidak diukur pada penelitian ini. Rumput gajah mini memiliki serat yang cukup tinggi sekitar 28\% (Sirait 2017) tetapi ayam broiler masih dapat mentolelir serat kasar yang dikonsumsinya sehingga pertumbuhan ayam broiler freerange tidak berbeda dengan intensif.

\section{Pengaruh Jenis Kelamin}

Ayam jantan memiliki postur tubuh yang lebih besar dibandingkan ayam betina. Perbedaan postur disebabkan oleh tingkat konsumsi pakan dan agresivitas yang tinggi pada ayam jantan (Kholik 2016). Hasil penelitian ini menunjukan perbedaan pada minggu ke-5 sedangkan minggu pertama dan ke-3 tidak terdapat perbedaan. Hasil pengukuran berdasarkan jenis kelamin disajikan pada Tabel 3. Hasil analisis ragam menunjukan jenis kelamin ayam
Tabel 2. Rataan hasil pengukuran morfometrik ayam betina

\begin{tabular}{|c|c|c|c|}
\hline \multirow[t]{2}{*}{ Peubah } & \multirow[t]{2}{*}{$\begin{array}{l}\text { Minggu } \\
\text { ke - }\end{array}$} & \multicolumn{2}{|c|}{$\begin{array}{l}\text { Rataan } \pm \text { sd Ukuran Tubuh pada } \\
\text { Sistem Pemeliharaan (mm) }\end{array}$} \\
\hline & & Intensif $(n=60)$ & $\begin{array}{l}\text { Free-range } \\
(\mathrm{n}=48)\end{array}$ \\
\hline \multirow[t]{2}{*}{ Panjang paruh } & 3 & $23,95 \pm 2,06$ & $23,82 \pm 1,16$ \\
\hline & 5 & $27,97 \pm 2,00$ & $27,28 \pm 2,16$ \\
\hline \multirow[t]{2}{*}{ Panjang shank } & 3 & $48,70 \pm 5,97$ & $48,56 \pm 6,78$ \\
\hline & 5 & $63,04 \pm 9,36$ & $61,93 \pm 8,38$ \\
\hline \multirow[t]{2}{*}{ Panjang tibia } & 3 & $79,78 \pm 7,17 b$ & $75,30 \pm 10,71 \mathrm{a}$ \\
\hline & 5 & $87,81 \pm 9,38$ & $89,20 \pm 11,04$ \\
\hline \multirow[t]{2}{*}{ Panjang femur } & 3 & $60,98 \pm 4,59 b$ & $58,14 \pm 6,97 \mathrm{a}$ \\
\hline & 5 & $75,23 \pm 8,48$ & $72,45 \pm 8,22$ \\
\hline \multirow[t]{2}{*}{ Panjang sayap } & 3 & $153,55 \pm 18,83$ & $155,68 \pm 16,22$ \\
\hline & 5 & $201,66 \pm 16,35$ & $198,59 \pm 15,10$ \\
\hline \multirow[t]{2}{*}{ Dalam dada } & 3 & $71,36 \pm 6,25$ & $68,6 \pm 11,60$ \\
\hline & 5 & $84,37 \pm 8,95$ & $82,05 \pm 9,56$ \\
\hline \multirow[t]{2}{*}{ Lebar dada } & 3 & $60,86 \pm 5,79$ & $58,54 \pm 9,41$ \\
\hline & 5 & $87,30 \pm 9,58$ & $84,47 \pm 10,46$ \\
\hline \multirow[t]{2}{*}{ Panjang dada } & 3 & $95,05 \pm 7,37$ & $94,61 \pm 9,21$ \\
\hline & 5 & $142,90 \pm 13,05$ & $140,69 \pm 13,91$ \\
\hline \multirow[t]{2}{*}{ Panjang leher } & 3 & $86,72 \pm 19,51$ & $88,96 \pm 23,65$ \\
\hline & 5 & $107,67 \pm 16,67$ & $107,40 \pm 15,68$ \\
\hline \multirow[t]{2}{*}{ Panjang punggung } & 3 & $140,22 \pm 14,70$ & $136,06 \pm 13,88$ \\
\hline & 5 & $150,83 \pm 12,20$ & $150,31 \pm 13,54$ \\
\hline \multirow[t]{2}{*}{ Lingkar dada } & 3 & $230,05 \pm 14,53$ & $228,85 \pm 23,33$ \\
\hline & 5 & $314,02 \pm 29,96$ & $318,98 \pm 36,15$ \\
\hline
\end{tabular}

mempengaruhi hampir seluruh peubah yg diukur kecuali panjang dada dan panjang paruh. Lingkar dada, panjang sayap, panjang femur, panjang tibia, dan panjang shank ayam jantan nyata $(\mathrm{P}<0,05)$ lebih besar dari pada ayam betina. Panjang punggung, panjang leher, lebar dada, dan dalam dada ayam jantan sangat nyata $(\mathrm{P}<0,01)$ lebih besar dari pada ayam betina. Hal ini disebabkan ayam jantan memiliki hormon testosteron yang lebih banyak dan lebih agresif. Hormon testosteron dapat merangsang peningkatan sekresi growth hormone (GH). Growth hormone mampu merangsang pertumbuhan yang lebih cepat dengan cara mempercepat pembelahan sel dan sintesis protein (Ma'ruf 2004).

\section{Pertumbuhan Kerangka Ayam}

Pertumbuhan kerangka ayam broiler jantan pada sistem pemeliharaan intensif, ayam broiler betina pada sistem pemeliharaan intensif, ayam broiler jantan pada sistem pemeliharaan free-range, dan ayam broiler betina pada sistem pemeliharaan free-range disajikan pada Tabel 4. Data yang disajikan menunjukan kerangka ayam broiler terus tumbuh secara cepat pada minggu pertama sampai minggu ke-3.

Ternak mengalami pertumbuhan cepat sejak lahir hingga dewasa kelamin (Ashifudin 2017). Hampir seluruh tulang pada tubuh ayam mengalami pertumbuhan lebih dari 
Tabel 3. Rataan hasil pengukuran berdasarkan jenis kelamin di minggu ke-5

\begin{tabular}{lcc}
\hline Peubah & \multicolumn{2}{c}{ Rataan \pm sd Ukuran Tubuh $(\mathrm{mm})$} \\
\cline { 2 - 3 } & Jantan $(\mathrm{n}=84)$ & Betina $(\mathrm{n}=108)$ \\
\hline Panjang paruh & $27,82 \pm 2,31$ & $27,66 \pm 2,09$ \\
Panjang shank & $65,41 \pm 9,73 \mathrm{~b}$ & $62,54 \pm 8,92 \mathrm{a}$ \\
Panjang tibia & $92,42 \pm 11,36 \mathrm{~b}$ & $88,43 \pm 10,13 \mathrm{a}$ \\
Panjang femur & $76,95 \pm 8,19 \mathrm{~b}$ & $73,99 \pm 8,44 \mathrm{a}$ \\
Panjang sayap & $209,83 \pm 16,98 \mathrm{~b}$ & $200,29 \pm 15,81 \mathrm{a}$ \\
Dalam dada & $88,61 \pm 11,81 \mathrm{~b}$ & $83,34 \pm 9,25 \mathrm{a}$ \\
Lebar dada & $91,05 \pm 8,85 \mathrm{~b}$ & $86,04 \pm 10,04 \mathrm{a}$ \\
Panjang dada & $145,19 \pm 15,90$ & $141,92 \pm 13,42$ \\
Panjang leher & $116,21 \pm 18,11 \mathrm{~b}$ & $107,55 \pm 16,16 \mathrm{a}$ \\
Panjang punggung & $156,18 \pm 13,75 \mathrm{~b}$ & $150,60 \pm 12,75 \mathrm{a}$ \\
Lingkar dada & $330,11 \pm 23,91 \mathrm{~b}$ & $316,22 \pm 32,79 \mathrm{a}$ \\
\hline
\end{tabular}

Keterangan: Angka disertai huruf berbeda pada baris yang sama menunjukan berbeda nyata $(\mathrm{P}<0,05)$

Tabel 4. Data pertumbuhan kerangka ayam

\begin{tabular}{|c|c|c|c|c|c|}
\hline \multirow[t]{3}{*}{ Peubah } & \multirow[t]{3}{*}{$\begin{array}{l}\text { Minggu } \\
\text { ke - }\end{array}$} & \multicolumn{4}{|c|}{$\begin{array}{c}\text { Pertumbuhan Ukuran Morfomertrik } \\
\text { Ayam (\%) }\end{array}$} \\
\hline & & \multicolumn{2}{|c|}{ Intensif } & \multicolumn{2}{|c|}{ Free-range } \\
\hline & & Jantan & Betina & Jantan & Betina \\
\hline \multirow[t]{2}{*}{ Panjang paruh } & $\Delta 1-3$ & 38,22 & 30,93 & 33,15 & 33,52 \\
\hline & $\Delta 3-5$ & 16,45 & 16,79 & 16,05 & 18,92 \\
\hline \multirow[t]{2}{*}{ Panjang shank } & $\Delta 1-3$ & 61,38 & 54,75 & 58,63 & 55,05 \\
\hline & $\Delta 3-5$ & 31,19 & 29,44 & 29,01 & 27,52 \\
\hline \multirow[t]{2}{*}{ Panjang tibia } & $\Delta 1-3$ & 65,33 & 65,84 & 63,34 & 62,02 \\
\hline & $\Delta 3-5$ & 19,05 & 10,06 & 17,81 & 18,46 \\
\hline \multirow[t]{2}{*}{ Panjang femur } & $\Delta 1-3$ & 74,57 & 78,28 & 67,51 & 74,16 \\
\hline & $\Delta 3-5$ & 29,57 & 23,38 & 28,21 & 24,60 \\
\hline \multirow[t]{2}{*}{ Panjang sayap } & $\Delta 1-3$ & 66,92 & 64,15 & 72,03 & 67,26 \\
\hline & $\Delta 3-5$ & 37,14 & 31,33 & 35,19 & 27,56 \\
\hline \multirow[t]{2}{*}{ Dalam dada } & $\Delta 1-3$ & 74,68 & 52,96 & 67,31 & 67,21 \\
\hline & $\Delta 3-5$ & 24,80 & 18,22 & 21,74 & 19,61 \\
\hline \multirow[t]{2}{*}{ Lebar dada } & $\Delta 1-3$ & 80,17 & 80,67 & 76,42 & 71,59 \\
\hline & $\Delta 3-5$ & 49,18 & 43,45 & 48,07 & 44,29 \\
\hline \multirow[t]{2}{*}{ Panjang dada } & $\Delta 1-3$ & 100,92 & 101,39 & 105,19 & 99,33 \\
\hline & $\Delta 3-5$ & 48,63 & 49,19 & 50,44 & 58,77 \\
\hline \multirow[t]{2}{*}{ Panjang leher } & $\Delta 1-3$ & 102,03 & 81,86 & 91,35 & 82,37 \\
\hline & $\Delta 3-5$ & 27,03 & 24,16 & 23,45 & 20,73 \\
\hline \multirow[t]{2}{*}{ Pjg punggung } & $\Delta 1-3$ & 78,47 & 80,54 & 69,43 & 72,42 \\
\hline & $\Delta 3-5$ & 11,33 & 7,57 & 16,27 & 10,47 \\
\hline \multirow[t]{2}{*}{ Lingkar dada } & $\Delta 1-3$ & 90,91 & 84,93 & 80,64 & 82,96 \\
\hline & $\Delta 3-5$ & 42,09 & 36,50 & 39,51 & 41,20 \\
\hline
\end{tabular}

50\% pada umur 1 minggu sampai umur 3 minggu kecuali panjang paruh. Panjang paruh mengalami pertumbuhan kurang dari $40 \%$. Panjang paruh ayam yang dipelihara pada free-range memiliki pertumbuhan yang lebih seragam antara ayam jantan dan ayam betina yaitu $33,15 \%$ dan
33,52\%. Albar (2018) menjelaskan semakin panjang paruh ayam diharapkan dapat meningkatkan konsumsi pakan pada ayam karena jarak jangkau untuk mematuk akan semakin pendek. Ayam yang dipelihara pada pemeliharaan intensif mangalami pertumbuhan tulang paruh $38,22 \%$ pada jantan dan betina 30,93\% saat umur 3 minggu. Hal ini dimungkinkan karena jantan lebih agresif dari betina sehingga pertumbuhan tulangnnya lebih optimal. Pertumbuhan tulang pada free-range cenderung sama antara jantan dan betina dimungkinkan di area free-range ayam betina lebih terpancing untuk mematuk rumput sehingga ayam betina free-range lebih banyak menggerakan paruhnya dibandingkan ayam intensif dengan demikian pertumbuhan paruh betina free-range cenderung sama dengan ayam jantan di free-range.

Minggu ke-3 menuju minggu ke-5 terus mengalami pertumbuhan yang pesat pada beberapa peubah yang diukur seperti pada sayap, lebar dada, panjang dada, dan lingkar dada. Tulang sayap merupakan tulang yang sangat sering digunakan untuk beraktivitas sehingga pertumbuhannya terus meningkat dengan optimal. Menurut Fortomaris (2006) bagian tubuh ayam yang lebih sering digerakkan memiliki pertumbuhan tulang yang lebih maksimal. Tulang tubuh ayam pada sayap dan dada masih mengalami pertumbuhan yang pesat sebesar $27,52 \%-58,77 \%$ seperti disajikan pada Tabel 4. Pertumbuhan ini dimungkinkan karena umur 5 minggu ayam belum mencapai dewasa kelamin sehingga pertumbuhan tulang masih sangat pesat (Ashifudin 2017).

Pertumbuhan tulang ayam jantan lebih besar persentasenya pada tulang sayap, lebar dada, dan lingkar dada. Sesuai dengan Mufti (2003) yang menyatakan ayam jantan memiliki ukuran tubuh yang lebih besar dari betina. Pertumbuhan panjang dada pada ayam betina lebih besar dari jantan. Hal ini dimungkinkan karena yang disajikan adalah persentase pertumbuhannya namunsecara fisik jantan lebih panjang pada umur yang sama, seperti disajikan pada Tabel 1 dan 2 bahwa rataan betina lebih rendah daripada jantan.

Tulang leher, femur, shank, dan dalam dada memiliki pertumbuhan yang mulai melambat pada minggu ke-3 sampai ke-5. Pertumbuhan bagian tersebut hanya bertambah paling tinggi 31,19\%. Semakin bertambah umur ayam pertumbuhan tulangnya akan semakin berkurang. Pada umur tertentu pertumbuhan tulang dan otot ayam akan berhenti karena sudah mencapai batasnya (Ashifudin 2017). Tulang paruh, tibia, dan punggung menunjukan persentase pertumbuhan yang paling kecil diantara yang lainnya yaitu di bawah $20 \%$ pada minggu ke-3 sampai minggu ke5. Penurunan percepatan pertumbuhan pada tulang tibia dimungkinkan pada umur 3 minggu bobot ayam broiler semakin meningkat sehingga mengakibatkan broiler suka bermalas-malasan (duduk) dan lebih sedikit menggerakan bagian tibia dan femur dibandingkan bagian shank.

Menurut Candrawati (2007) tibia merupakan salah satu tulang yang memiliki pertumbuhan lambat. Tulang punggung merupakan tulang yang sangat jarang untuk digerakan sehingga dapat mempengaruhi laju pertumbuhannya. Panjang paruh ayam betina free-range memiliki laju pertumbuhan yang paling besar. Hal ini dimungkinkan karena ayam yang dipelihara di free-range 
cenderung lebih aktif bergerak dan mengais-ngais tanah dibandingkan ayam yang dipelihara intensif.

Pertumbuhan tulang ayam selain dapat dilihat dengan laju pertumbuhan $(\Delta)$ yang diperoleh, dapat juga dilihat dengan kurva pertumbuhan tulang pada Gambar 3. Kurva pertumbuhan tulang ditampilkan dan memperlihatkan pertumbuhan tulang ayam yang diamati. Grafik yang lebih condong ke arah vertikal manandakanpertumbuhan tulang masih sangat cepat, sedangkan grafik yang cenderung condong ke arah horizontal menandakan mulai melambatnya pertumbuhan tulang ayam.

Gambar 3a-3k menunjukan pertumbuhan tulang pada ayam broiler masih terus tumbuh secara cepat pada minggu pertama sampai minggu ke-3. Broiler terus mengalami pertumbuhan yang pesat di minggu ke-3 menuju minggu ke-5 pada beberapa peubah yang diukur seperti pada tulang paruh, shank, sayap, lebar dada, panjang dada, dan lingkar dada. Tulang sayap, shank, dan paruh merupakan tulang

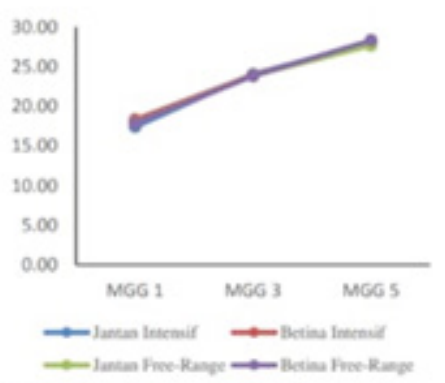

Gambar 3a Grafik pertumbuhan panjang paruh

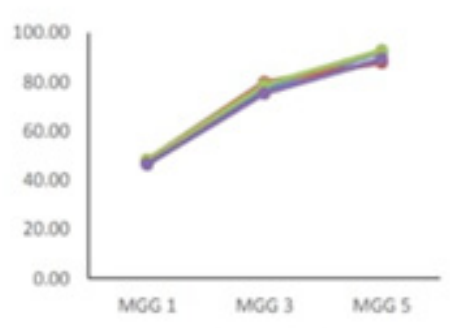

$\rightarrow$ lartan lmeneif
Gambar 3d Grafik pertumbuhan panjang tibia
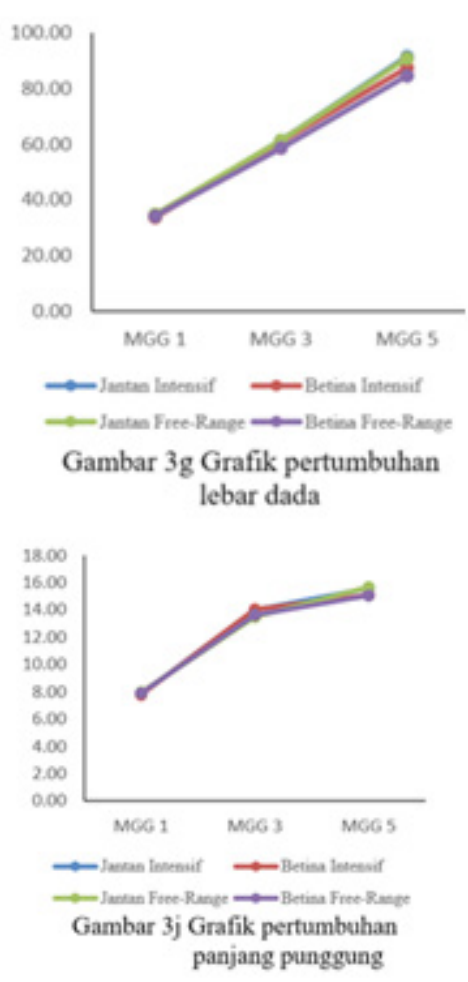

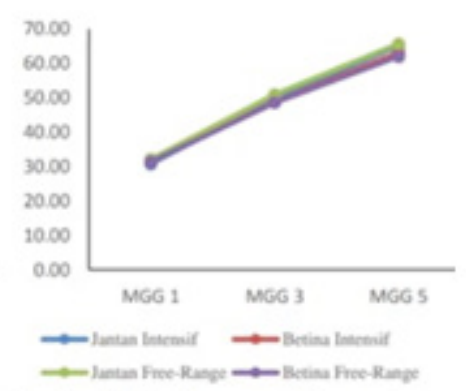

Gambar $3 b$ Grafik pertumbuhan panjang shank
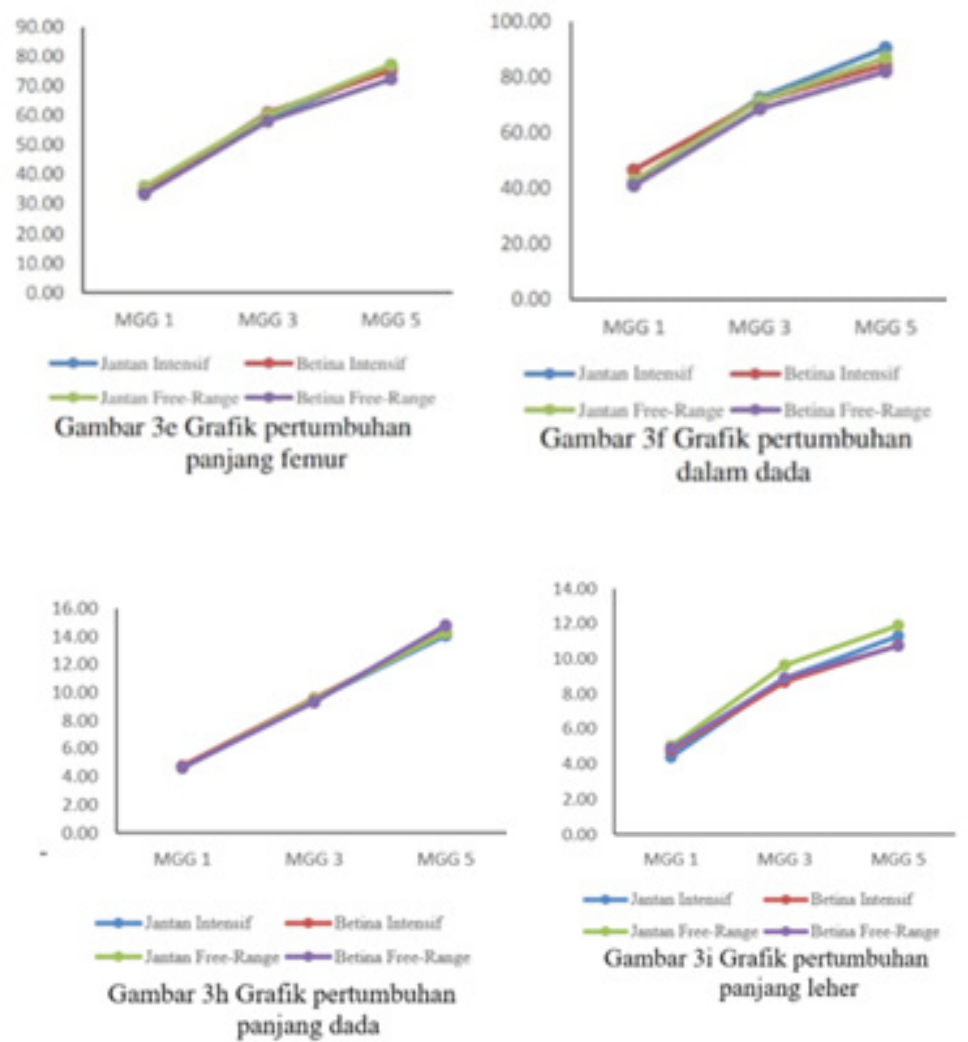

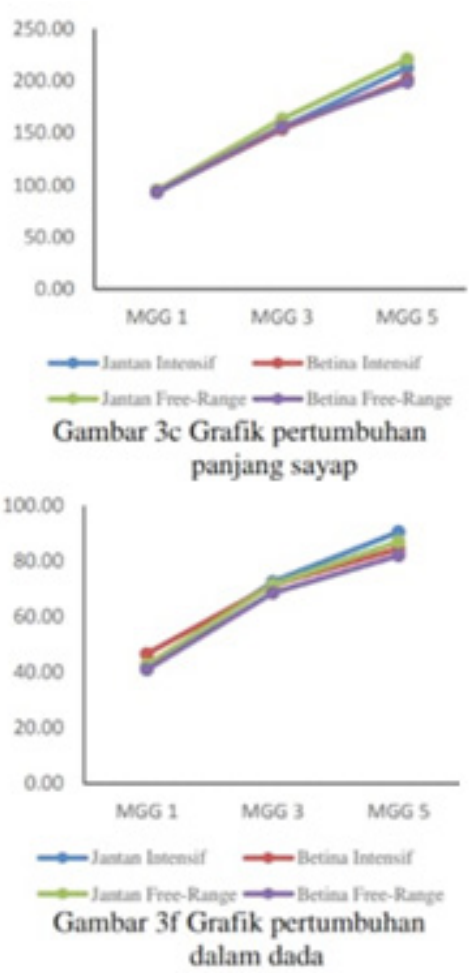

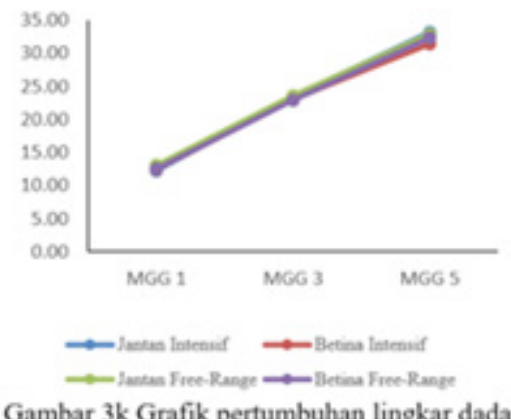


yang sangat sering digunakan untuk beraktivitas, sehingga pertumbuhannya terus meningkat dengan optimal.

Sesuai Fortomaris (2006) bagian ayam yang lebih aktif digerakkan memiliki pertumbuhan tulang yang lebih optimal. Pada minggu ke-3 pertumbuhan tulang tibia, femur, dalam dada, panjang leher, dan panjang punggung mulai menurun. Penurunan percepatan pertumbuhan pada tulang tibia dan femur dimungkinkan pada umur 3 minggu karena bobot ayam broiler semakin meningkat sehingga mengakibatkan broiler suka bermalas-malasan (duduk) dan lebih sedikit menggerakan bagian tibia dan femur dari pada bagian shank. Menurut Candrawati (2007) tibia merupakan salah satu tulang yang memiliki pertumbuhan lambat.

\section{KESIMPULAN}

Perlakuan sistem pemeliharaan tidak menunjukkan perbedaan pada ukuran morfometrik ayam yang diamati kecuali pada panjang tibia, panjang femur, dan panjang sayap. Jenis kelamin berpengaruh secara siginifikan terhadap morfometrik ayam diantaranya panjang shank, panjang tibia, panjang sayap, panjang femur, dan lingkar dada, pada lebar dada, dalam dada, panjang leher, dan panjang punggung pada sistem pemeliharaan intensif dan free-range di daerah tropis.

\section{DAFTAR PUSTAKA}

(BPS) Badan Pusat Statistik. 2016. Populasi Ayam Ras Pedaging menurut Provinsi (Ekor). Jakarta (ID): BPS RI.

(FAO) Food and Agriculture Organization of The United Nations. 2012. Phenotypic Characterization of Animal Genetic Resources. Animal Production and Health Guidelines No. 11. Roma (IT): FAO.

Albar, M. F. 2018. Pertumbuhan dan morfometrik G4 hasil persilangan ayam lokal dengan ayam ras pedaging (PSKM) umur 18 sampai 24 minggu. Skripsi. Bogor (ID): Institut Pertanian Bogor.

Ashifudin, M., E. Kurnianto, \& Sutopo. 2017. Karakteristik morfometrik ayam kedu jengger merah dan jengger hitam generasi pertama di satker ayam marontemanggung. Jurnal Ilmu Ternak. 17(1):40-46.

Candrawati, V. Y. 2007. Studi ukuran dan bentuk tubuh ayam kampung, ayam sentul dan ayam wareng tangerang melalui anaisis komponen utama. Skripsi. Bogor (ID): Institut Pertanian Bogor.

Castellini, C., C. Mugnai, \& A. Dal Bosco. 2002. Effect of organic production system on broiler carcass and meat quality. Meat Sci. 60:219-225.

Fortomaris, P., G. Arsenos, A. T. Gousi, \& A. Yannakopoulos. 2006. Performance and behaviour of broiler chickens as affected by the housing system. Arch. Geflüglek. 71(3): 97-104.

Glatz, P. C., Y. J. Ru, Z. H. Miao, S. K. Wyatt, \& B. J. Rodda. 2005. Integrating poultry into acrop and pasture farming system. Poult Sci. 4(4):187-191.

Golden, J. B., D. V. Arbona, \& K. E. Anderson. 2012. A comparative examination of rearing parameters and layer production performance for brown egg type pulletsgrown for either free-range or cage production. Appl Poult. 21:95-102.

Gordon, S. H., \& D. R. Charles. 2002. Niche and Organic Chicken Products. Nottingham (UK): University Pr.

Kholik, A., E. Sujana, \& I. Setiawan. 2016. Performa ayam hasil persilangan pejantan bangkok dengan betina ras petelur strain lohan. Skripsi. Bandung (ID): Universitas Padjadjaran.

Kiswanto, S. H., A. Fatikhunnada, \& M. Sholihudin. 2014. Aspek lingkungan dan produktivitas ayam broiler pada sistem transportasi tertutup dan konvensional. Pengolahan Sumberdaya Alam dan Lingkungan. 3(2):161-165.

Kurnianto, E., S. Sutopo, E. Purbowati, E. T. Setiatin, D. Samsudewa, \& T. Permatasari. 2013. Multivariate analysis of morfphological traits of local goats in Central Java-Indonesia. Iranian J App Anim Sci. $3(2): 361-367$.

Ma'ruf, A. 2004. Peran pengaturan waktu dan jumlah pemberian pakan terhadap sekresi growth hormon (GH) dan insulin-like growth factor I (IGF-I) dalam mempengaruhi sintesis lemak dan protein daging ayam pedaging. Disertasi. Surabaya (ID): Universitas Airlangga.

Mattjik, A. A., \& I. M. Sumertajaya. 2013. Perancangan Percobaan dengan Aplikasi SAS dan MINITAB. Bogor (ID): IPB-Pr.

Mishra, A., P. Koene, W. Schouten, B. Spruijt, P. Van Beek, \& J. H. M. Metz. 2005. Temporal and sequential structure of behavior and facility usage laying hens in an enriched environment. Poult Sci. 84 : 979-991.

Mufti, R. 2003 Studi ukuran dan bentuk tubuh ayam kampung, ayam pelung, dan persilangannya. Skripsi. Bogor (ID): Institut Pertanian Bogor.

Sirait, J. 2017. Rumput Gajah Mini (Pennisetum purpureum cv. Mott) sebagai hijauan pakan untuk ruminansia. Wartazoa 27(4) :167-176.

Sission, S., \& J. D. Grossman. 1953. The Anatomy of The Domestic Animals. Philadelphia (US-PA): Saunders.

Suparyanto, A., H. Martojo, P. S. Hardjosworo, \& L. H. Prasetyo. 2004. Kurva pertumbuhan morfologi itik betina hasil silangan antara peking dan mojosari putih. Jurnal Ilmu Peternakan dan Veteriner. 9(2):87-97.

Umam, M. K., H. S. Prayogi, \& V. M. A. Nurgiartiningsih. 2015. Penampilan produksi ayam pedaging yang dipelihara pada sistem pemeliharaan lantai kandang panggung dan kandang bertingkat. Jurnal Ilmu-ilmu Peternakan. 24(3):79-87. 